Portland State University

PDXScholar

Summer 9-1-2017

\title{
Investigating Cable: the Potential and Actual Value of PEG \& Franchise Fees
}

Duncan Chaz Stewart

Portland State University

Follow this and additional works at: https://pdxscholar.library.pdx.edu/open_access_etds

Part of the Communication Commons

Let us know how access to this document benefits you.

\section{Recommended Citation}

Stewart, Duncan Chaz, "Investigating Cable: the Potential and Actual Value of PEG \& Franchise Fees" (2017). Dissertations and Theses. Paper 3831.

https://doi.org/10.15760/etd.5725

This Thesis is brought to you for free and open access. It has been accepted for inclusion in Dissertations and Theses by an authorized administrator of PDXScholar. Please contact us if we can make this document more accessible: pdxscholar@pdx.edu. 
Investigating Cable: The Potential and Actual Value of PEG \& Franchise Fees

by

Duncan Chaz Stewart

A thesis submitted in partial fulfillment of the requirements for the degree of

Master of Science

in

Communication

Thesis Committee:

Lee Shaker, Chair

Cynthia-Lou Coleman

Jeffrey Robinson

Portland State University

2017 


\begin{abstract}
Cable Franchise Fees and PEG Fees function as key resources to the longevity of local media. Critics of the fees suggest that revenue earned from them is misplaced, and/or misused. This research examines the budgets of twenty US cities to determine how much money cities are collecting from these fees and where these funds are spent in an attempt to determine if the actual usages of Franchise and PEG Fee revenue corresponds to their theoretical benefits.
\end{abstract}




\section{ACKNOWLEDGEMENTS}

First I would like to thank Dr. Shaker. His advice, care, and attention to detail helped this project materialize. To my other committee members, Dr. Coleman and Dr. Robinson, thank you for the time, energy, and knowledge you have invested in my project, and me as a student.

I would also like to thank my friends, Tom Shcally and Conner Sabin for their consistent support and encouragement.

Finally, a thank you to the Portland State Communication Department and my cohort. It was a privilege to be a member of both. 


\section{TABLE OF CONTENTS}

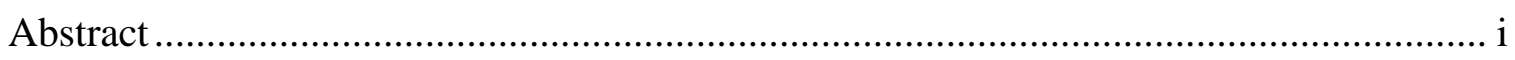

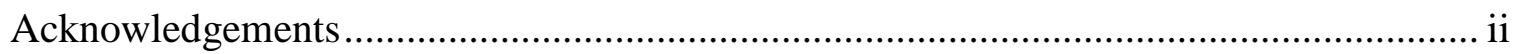

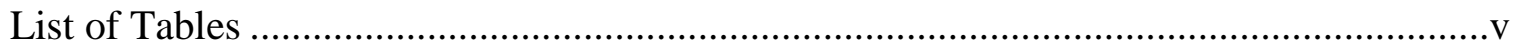

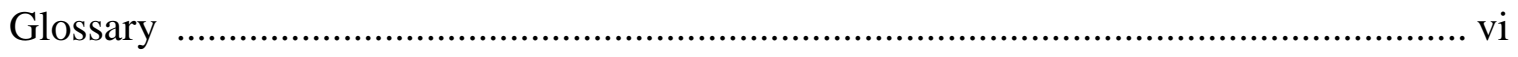

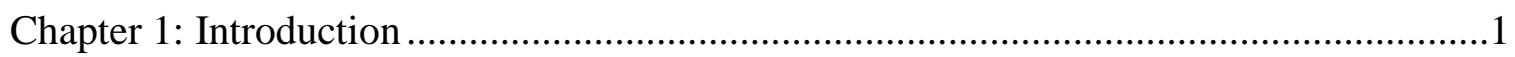

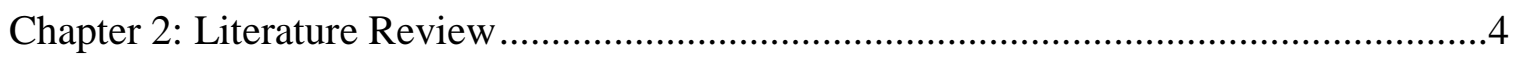

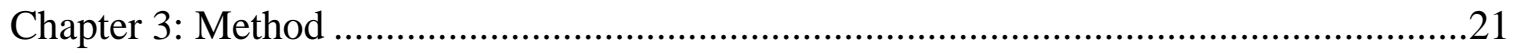

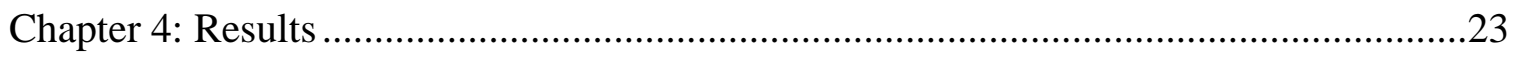

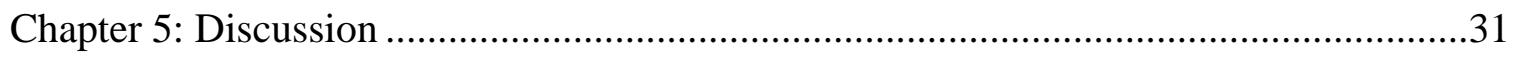

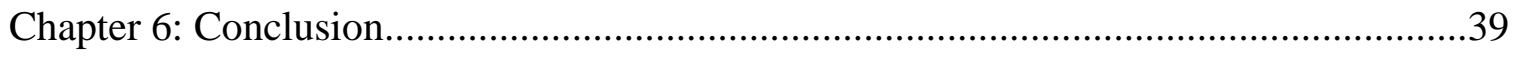

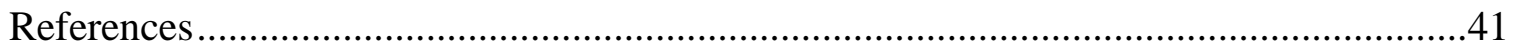

Appendices

A. Austin 2015-2016 Cable Finances Detailed..............................................45

B. Charlotte 2016-2017 Cable Finances Detailed..............................................46

C. Chicago 2015-2016 Cable Finances Detailed ..............................................47

D. Columbus 2015-2016 Cable Finances Detailed...........................................48

E. Dallas 2015-2016 Cable Finances Detailed ..............................................49

F. Detroit 2015-2016 Cable Finances Detailed..................................................50

G. El Paso 2015-2016 Cable Finances Detailed .............................................51

H. Fort Worth 2015-2016 Cable Finances Detailed ........................................52

I. Houston 2015-2016 Cable Finances Detailed ................................................53 
INVESTIGATING CABLE $\quad$ iv

J. Indianapolis 2016-2017 Cable Finances Detailed.........................................54

K. Jacksonville 2015-2016 Cable Finances Detailed .......................................55

L. Los Angeles 2015-2016 Cable Finances Detailed..........................................56

M. New York 2015-2016 Cable Finances Detailed...........................................57

N. Philadelphia 2015-2016 Cable Finances Detailed ........................................58

O. Phoenix 2015-2016 Cable Finances Detailed ..................................................59

P. San Antonio 2015-2016 Cable Finances Detailed.......................................60

Q. San Diego 2015-2016 Cable Finances Detailed ...........................................61

R. San Francisco 2015-2016 Cable Finances Detailed.....................................62

S. San Jose 2015-2016 Cable Finances Detailed .............................................63

T. Seattle 2015-2016 Cable Finances Detailed..................................................64

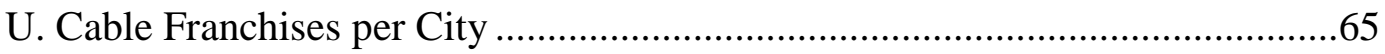




\section{LIST OF TABLES}

Table 1

Collection of Fees

Table 2

Cable Related City Finances

Table 3

Expenditures per Category from Cable Revenue....................................................29 


\section{GLOSSARY}

Cable Act: The Cable Communications Policy Act of 1984 amended The Communications Act of 1934 by adding a title named "Cable Communications" which outlined the process for franchise agreements between cable companies and municipalities. This included the federal authorization of a municipality's right to collect a PEG Fee and Franchise Fee.

Federal Communications Commission: The federal body in the United States that operates independently to create and oversee laws regarding the operation and consumption of mass media.

Franchise agreement: A contract that allows the franchisor (municipality) to specify the conditions by which the franchisee (cable company) may do business. These are regularly used to grant an investor permission to use the business model or intellectual property of a pre-existing company. For the purposes of this resarch a franchise agreement refers to the legally binding conditions the cable company agreed to in exchange for the rights to use the public right of way. These conditions may include the collection of fees.

Franchise Fees: Plainly, a fee an investor pays to operate a franchise. For this research a Franchise Fee refers to the optional fee a municipility charges to a cable company for use of the public right of way. The fee may be set at up to $5 \%$ of the gross revenue earned by the cable company. In actuality citizens pay this fee instead of the cable company because the FCC approved cable companies' right to pass the fee along to the consumer as long as the fee is line-itemed on the customer's bill. Revenue from the Franchise Fee may be spent however the municipality chooses.

Local Franchising Authority: (LFA) Are the local agencies that oversee FCC regulations within a given locale. They are responsible for the collection of PEG and Franchise Fees in addition to enforcing other rules and regulations on cable television.

Public right of way: A right to equtiable and public use of a piece of land for a desiginated purpose. For example, sidewalks are public, equal use, and for walking. Roads are public and for operating vehicles. Cable companies must use the public roadways for private enterprise in order to lay cable in a city. The FCC requires that the public be compensated for the cable companies use of public land by payment to the city (franchise agreement).

PEG Fee: An optional fee a municipality may levy as part of a franchise agreement. There is no cap on this fee, but revenue must be used for the capital costs incured by Public, Education, and Government (PEG) media infrastructure. In actuality citizens pay this fee instead of the cable company because the FCC approved cable companies' right to pass the fee along to the consumer as long as the fee is line-itemed on the customer's bill. 


\section{CHAPTER 1: INTRODUCTION}

Every month cable-subscribing-citizens in the United States pay fees that are levied by cities on cable companies, and in turn passed onto them by those companies. It is likely that subscribers who have never reviewed the line-items of their cable bill are unaware of these charges. In Austin these fees totaled an estimated $\$ 73^{1}$ per cable subscribing household across twelve months in 2016. These charges are composed of two things: Franchise Fees and PEG Fees.

In theory, revenue earned from each fee functions as repayment to the public for the costs incurred by private cable enterprises on public land but, in practice, the fees are an additional monthly charge to cable viewers. To mandate this theoreitical repayment, the Federal Communications Commission (FCC) developed the 1984 Cable Franchise Policy and Communications Act which outlines the details of the two fees. The Franchise Fee, an up to $5 \%$ tax on the gross revenue earned by a cable company that the city may spend however it wishes, and the PEG Fee, which can be levied at any percentage, and must be used for providing media resources to local public, educational, and government institutions. Combined, the fees' revenue ensures that municipalities can endure the costs of cable operations, and provide resources for the creation and broadcast of local media by the public against the backdrop of corporate cable. However, pursuant to (47 U.S. Code $§ 542$ ) the cable company may line item PEG Fees and Franchise Fees on the customer's bill, passing the cost onto the consumer, and creating a disconnect between the theory of what the fees ought to do and the practice of what they actually do.

\footnotetext{
${ }^{1}$ See page (27)
} 
Despite charging the public an additional tax instead of reimbursing them, the fees may still contribute to the public good. The cumulative revenue generated by PEG and Franchise Fees for cities is substantial. For example, in 2011 San Francisco collected upwards of \$10 million in Franchise Fees alone (Waldman, 2011). These funds, along with those generated from the PEG Fee, have historically been used to bolster local media through the funding of public access channels, schools, and libraries. This funding strengthens the local information systems that are required components of democratic societies by financing institutions responsible for the distribution of local media. Information on local governmental action and current events is essential to political agency because knowledge of such affairs facilitates informed voting, community advocacy, institutional decision making, and civic engagement (Shaker, 2009; Starr, 2011).

Notwithstanding the magnitude and historical use of the fees, it is unclear how the revenue from them is being used today. A recent law suit asserted that Portland, Oregon had misallocated \$14 million of Franchise and PEG Fee revenue, though the suit never saw trial (Rogoway, 2016; Rogoway, 2017). Others have reported logistical concerns, noting that when money is collected only a portion of it reaches the public (Waldman, 2011).

Thus, to determine whether or not major cities are collecting these fees, and the manner in which they are spent, this research audits the most recently published annual budget of each of the twenty largest cities in the US. In documenting the costs and allocations of the two fees this research begins a larger conversation about the purpose 
and function of the fees, their role in the digital era, and whether or not they are living up to their potential of bringing important local media resources and content to the public.

After all, the fees ought to benefit the public because everyday citizens, not the cable companies, are paying them. 


\section{CHAPTER 2: LITERATURE REVIEW}

Foundational theories of democracy informed the decision making processes that would later shape the Cable Act and the particular fees concerning this research. These theories demonstrate the importance of localism in democratic politics. For example, Mill (1865) argued that organizations for "local affairs are...fundamental institutions of a free government” (p.319). From this perspective, localism distributes governing power more closely to the private citizen by providing a greater opportunity to participate in, and be elected to make decisions about matters that directly affect their lives. Locating political power closer to the individual and their proximal influence has long been the motivation for sustaining local politics in the US even if at the cost of federal power (Briffault, 1990; Napoli, 2001). Critical to the health of local politics is local media. Theoretical and empirical works demonstrate that the newspaper, televised news, and public radio broadcast have long been the impetus for defining the boundaries of, and encouraging participation in local politics (Napoli, 2001; Baker, 2007; Shaker, 2014).

\section{Localism from Theory to Policy}

In the context of communication policy, localism is broadly utilized as a catch-all term to suggest that communication infrastructure should be crafted around the needs of local communities to enrich a sense of local identity and strengthen participation in democratic institutions. Local media is the evident linchpin of such matters as they provide the shared information basis used to create a sense of local politics amongst citizens. Tarde (1903) writes that early newspapers defined the boundaries of community as they set common topics of discussion among residents in a given area. Collectively understood topics for public dialogue cultivate and solidify a public identity as they 
reveal events that have mutual effects on both private and neighborly affairs. Further, in the most fundamental way, local media are critical to establishing community-based political associations as they construct the identity around which local interlocutors organize.

The value of local politics is among the starting points from which the FCC crafts its policies. Napoli (2001) refers to these starting points as the founding principles of the FCC which include adherence to the First Amendment, the public interest, the marketplace of ideas, diversity, competition, universal service, and of chief importance to this research: localism. At the institutional center of the FCC's policy making process these principles function as guiding rules, the justification for revising antiquated laws, and the filter for implementing new ones.

True to its principle of localism, the FCC has a legacy of safeguarding the production of local political information by ensuring local media remain permanent fixtures across the national media landscape. For example, the Radio Act of 1927 reserved bands of frequency and time slots for the broadcast of community radio. Carter Mountain Transmission Corporation v. Federal Communications Commission and many similar cases crystallized the FCC's commitment to localism. Here, and in the federal litigation that followed, the FCC strengthened their regulatory power by extending their jurisdiction to the regulation of cable television. Napoli (2001) writes that the FCC had determined that localism was a sufficiently important federal objective to curb the First Amendment rights of cable companies in favor of a mandate that cable carriers reserve space and resources for public access television. In 1967, Congress created public 
television under the rationale that broadcasting should serve both a mass audience and the diverse cultural interests within those masses (Napoli, 2001). Since then, the FCC has engineered policy infrastructure to maintain and nurture what has been called "the public's soapbox, or the electronic equivalent of the printed leaflet'-public access television (Linder, 1999, p.xxvi). Materially, this infrastructure is subsidized by the resources locales derive from PEG and Franchise Fees.

Baker (2007) provides theoretical justifications for the regulatory protection of local media. He argues that the "one-person/one-unit-of-political-power" applies not only to voting, but to participation in the public sphere as well (p.7). Indeed those with the means to broadcast political positions to mass audiences have disproportionate access to the public sphere, and by extension more units of political power compared to the average person. Often, their broadcasts may push local matters to the periphery in favor of a more profit-seeking or national focus. Regulation seeks to correct for this by providing platforms for the common person to spread their ideas and engage in local political dialogue. Baker (2007) further explains that media is the mediator between the will of the people and governments. Mass media simultaneously serves the role of a fourth-estate check on governmental action, while also providing reporting which serves to enunciate, at least a perception of public opinion to governments. Absent regulation, Baker fears that media ownership concentration threatens this relationship by reducing the number of outlets, especially at the local level, that can function as a necessary check on governments, corporate corruption, and misinformation. 
In the spirit of regulating on the behalf of local media to protect them from the forces of unobstructed market control, the FCC provisioned the Cable Act with tools that locales may utilize to strengthen public television. After approximately a decade of legal battles following the invention of cable television in Pennsylvania, United States $v$. Southwestern Cable determined that the FCC held the authority to regulate cable television (CATV) because it was in the scope of the institution's organic legal authority, and in the public interest. The Supreme Court ruling provided the constitutional backing by which the FCC mandates channel carriage requirements for cable companies to this day. Among the first of these was the requirement for all companies with over 3,500 subscribers to provide and carry all local television channels broadcast within a locality, beginning the federal subsidization and protection of local television. Within this regulatory framework, a local authority was needed to ensure that carriers were meeting their obligations, so Local Franchising Authorities (LFAs) were established. An LFA broadly refers to the local body that works with the FCC to enforce communication law, and they can be a municipality, a county, and occasionally a state.

The Cable Act, and its revisions, allow LFAs to charge cable networks operating within their field of influence two fees (though these are ultimately passed on to subscribers by cable companies). The first is a Franchise Fee, which an LFA may charge in exchange for allowing the cable provider to use the public right of way for equipment (e.g. cable lines buried beneath local roads). Franchise Fees can be charged up to an amount of $5 \%$ of the cable company's gross revenue on cable, and are routed back to the city in which a cable provider operates. The FCC does not mandate the funds are spent in 
any particular way, and it may not be legally defined as a PEG Fee within franchising agreements reached after 1984 (47 U.S. Code $§ 542$ ). Separate from the Franchise Fee then, the Cable Act provides the ability for LFAs to also levy PEG Fees, which must be spent in particular directions. The percentage of the PEG Fee is set by the LFA, and the proceeds must be used for public access broadcasting, educational media and broadcasting, and/or government access television. Limiting the allowed uses of capital earned from the fee even further, the FCC holds that PEG Fees may only be used for the capital costs incurred for PEG access facilities (Bolema, 2008). Recently, the 6th Circuit Court affirmed that PEG fees must be spent on capital costs (Alliance for Community Media v. FCC, 2008). This ruling also made clear that the operational definition of capital costs according to Congress "may include vans, studios, cameras, or other equipment relating to the use of public, educational, or governmental channel capacity." (Sixth Circuit Court, 2008, p.18). Thus, capital costs are not only limited to the operation of a facility, but the total costs incurred to outfit a PEG facility or program. Though the legal debate continues, outside of staff costs, PEG facilities may largely spend funds how they see fit to run their programs.

\section{Empirical Importance of Local Media}

In addition to the theoretical significance between media and localism, modern works continue to expound on the relationship between local media and various political correlates through empirical observation. Such observations continue to highlight the importance of fortifying local media via communication policy. Shaker (2014) evidences the adverse consequences the loss of a local news source can have on civic engagement. 
Even in a large metropolitan area like Denver, Colorado civic engagement declined by a measure of $30 \%$ when a local newspaper closed (Shaker, 2014). As the number of outlets for local information declines so does participation in that political sphere (Kaniss, 1997; Friedland \& McLeod, 1999). The closure of a city newspaper or television station means that a major, perhaps at times the only, vehicle for communicating important events and governmental concerns about the community is lost. Empirical findings from various works (Mondak 1995; Schulhofer-Wohl \& Garrido, 2011; Shaker, 2014) confirm that compared to those with access to local media, those without, or who have recently lost access to their source, showed lower rates of local political knowledge and community attachment. Hence, the disappearance of local media causes local political participation to wane by extinguishing the resources necessary to participate in governance. Similarly, Moy, McCluskey, McCoy, and Spratt (2004) demonstrate that attention to local news increases political knowledge and political participation among locals. Access then, tends to create more informed political decision making at the local level by encouraging a proliferation of political knowledge that might otherwise not occur. Situating the power of self-rule in spatially and socially close publics magnifies the political agency of their occupants. In sum, local media is a pillar of democratic politics. If the quality and accessibility of local political information deteriorates, so too might the strength of local democracies.

\section{The Modern Media Landscape and Stakeholders in PEG and Franchise Fees}

Regulating the market on the behalf of local media has become of heightened importance. The last comprehensive evaluation of US media by The Pew Research 
Center revealed daily local newspaper revenue declining by $8 \%$, the worst economic year for the local paper since the Great Recession (Barthell, 2016). Further, local television channels are steadily losing revenue. In 2015 , they lost $7 \%$ in advertising revenue (Barthell, 2016). Revenue continues to rise for cable companies, but subscriptions are declining overall (Barthell, 2016; Waldman, 2011). With newspapers struggling to survive, local television cutting costs, and many foregoing the subscriptions that give them access to coverage on local matters, sources of local political information are dwindling. The need for regulatory intervention becomes more pressing as these trends continue. However, it remains yet to be determined if PEG and Franchise Fees are the appropriate policies.

Stakeholders across diffuse socio-political spheres hold diverging perspectives on the role the two fees play in preserving local media and politics in the digital age. For the cable subscribing local the PEG Fee and Franchise fee is not only meant to subsidize local media, it is also intended to function as repayment for a carrier's operation in a city as they have to fracture roadways to lay cable. The costs of this are absorbed by the public via taxes that pay for road construction and through wear on personal vehicles. At the same time cable companies are afforded protection in the marketplace in the area because it does not make logistic or contractual sense to lay cable twice. Hence, a city will regularly only make franchise deals with a single cable company. Plainly then, the public contributes to the earnings of carriers. From the public's postion this necessitates both a tax on cable companies and the need for non-private public programming. A tax because the city is owed repayment to repair and re-invest in the publically shared 
roadways, and a reservation of space and resources for non-private programming on air so a single company cannot have unilateral control over public consumption of television media. However, the tax on cable companies is instead passed on to the public, which creates a flaw in this logic of repayment. The totality of PEG and Franchise Fee revenue is funded solely by the millions of homes throughout the United States with a cable subscription. Yet it remains uncertain if this value is returned to those households in a meaninfgul way. More precisely, it is not certain that the households in Austin that pay $\$ 73$ in Franchise Fees a year are returned that value in public projects.

From the cable companies' point-of-view PEG and Franchise Fees may be antiquated products of a past media landscape which make it more difficult to compete against digital television. As a result of passing both fees off to the consumer, cable bills are higher than digital-only services that depend on broadband delivery which is not subject to PEG or Franchise Fees. This does little to make cable television a more compelling option than subscriotion based interenet TV. The rise of internet based TV has resulted in cable subscriptions declining. In 2015, one in seven Americans had cancelled their cable subscriptions after previously being a customer (Horriggan \& Duggan, 2015). In 2016, this number reached one in five (Pressman, 2016).

From a governmental perspective PEG and Franchise funds are a major source of capital that municipalities may use for special projects like infrastructure repair, and/or renovations like the building of a new library. PEG funds in particular have been used by municipal public safety offices. For example, in Illinois PEG funds "provided disaster coverage and assistance when an 80-to-90-mile-per-hour wind tore through town in 
2007” (Waldman, 2011, p.171). In many cases, PEG financed channels spread severe weather warnings, disseminate information about disaster aid and relief, and report on missing persons after disasters. Despite the governmental advantages, the fees may provide there exists no check on how cities utilize the fees outside of what they selfreport in their budgets. In evaluating whether or not the fees are still a relevant contributor to the public good there must be a budgetary review to determine if the funds average households contribute to these programs are re-invested in their direction, or disbursed elsewhere.

\section{Past, Present, and Future of PEG and Franchise Fees}

Ideally, revenue from PEG Fees is used for the public good. For example, PEG programs often reflect diverse characteristics of the people in a locale that might otherwise not be captured in the spectrum of cable broadcasts. "In Minnesota, the Saint Paul Neighborhood Network (SPNN) offered eight programs for the growing Somali population in the area" (Waldman, 2011, p.171). Additionally, throughout the United States public access channels provided programming in "Greek, Czech, Hungarian, Albanian, German, French, Portuguese, Vietnamese, Chinese, Korean, Hmong, Farsi, Arabic, Hebrew, and Swahili” (Waldman, 2011, p.171). PEG funding provides the means for diverse populations to gain access to information that is vital to cultural enrichment, political self-determination, and the actualization of community.

Absent public access media funded by PEG, specific groups of non-English speaking people in a locale may not have access to news media. For example, it is unlikely for there to be a textual publication of local news in Swahili. PEG funds increase 
the potential for a diverse set of political interests to be heard in the public sphere by providing access to that sphere. Without PEG funds certain, often marginalized, community members may go without access to local information, relegating the domain of local politics to an already in-group. This dynamic stifles the democratic process at the local level because it creates and excludes outgroups from the decision making processes that affect their daily lives. Information bases and a willingness to involve oneself in local politics have profound practical effects on local democracies because locals who regularly consume local media are more likely to vote, attend neighborhood meetings, and mobilize themselves to positively shape their publics.

PEG programs have also provided media resources to local public schools. PEG funds are the reason that millennials may remember programing like The Reading Rainbow and Bill Nye the Science Guy as core parts of their curriculum. Which is to say PEG revenue has often been used to acquire the neighborhood elementary school's televisions and computers. In fact, PEG funding is crucial to providing public schools with a variety of media equipment for diverse purposes. For example, public access channels are the ones that will cover the local high school basketball game encouraging a shared sense of local identity. PEG funds have also been used to provide broadband access to community library centers and high schools, supplying students and community members with the countless benefits of the internet when they otherwise might not have access.

PEG monies have also be used to fund the creation of public programming for and by locals. Kalamazoo, Michigan's Public Media Network offers vocational courses in 
video production. Waldman (2011) notes that the average size PEG center can furnish the necessary training and equipment for up to 200 community video specialists annually. Community access programming may be the domain of tin-foil-hat-wearing late night talk specials, and the premise of the cult classic comedy Wayne's World, but it is also an opportunity for anybody with an idea to broadcast it to their community. Giving the public an ability to create and broadcast televised content redistributes access to the public sphere. This provides potential political platforms for those who may not own a studio or their own newspaper. In this way PEG law at time provides for the so-called electronic leaflet, perhaps strengthening the mediation between people and their governments at the local level, and advancing the check on institutional corruption Baker (2007) called for.

Finally, PEG Fees may benefit governmental transparency at the local level. Government channels provide floor coverage of city council meetings and similar events that would otherwise be inaccessible to the public. Waldman (2011) reports that CCTV, the public channel in Salem, Oregon, has televised 2,200 government meetings which would have gone without coverage from larger media. Broadcasting political information creates an archive of what was said about the decisions that will affect citizens' day to day lives. It also means journalists have a record to hold local politicians accountable to in later interviews. Thus PEG media is vital to local civic agency, especially in smaller rural and suburban media markets that may have coverage of the events occurring in more populated surrounding cities via commercial media that may not cover public policy of outer-lying areas. 
Present day implementation of PEG and Franchise Fees at the business and government levels might mitigate their possible advantages. First, state law often supersedes federal PEG guidelines. Cable operators were allowed to reduce PEG support by nearly $\$ 600,000$ in San Francisco County because the state adjusted the total amount of fees an LFA can collect by instituting a more limiting cap on the fee. (City and County of San Francisco Comments, 2009). Additionally, a legal claim filed in the Multnomah County Circuit Court during November of 2016 claims that the city of Portland and four of its surrounding communities misallocated more than fourteen-million dollars earned from PEG Fee revenue collected from cable companies that year (Rogoway, 2016). The plaintiff in this action suggested that there is a risk funds went to paying salaries of public officials, and/or to projects completely unrelated to public media access rather than their designated purpose. The case was later dismissed on the grounds that the plaintiff failed to show damage or injury from the misallocation (Rogoway, 2017). Local courts and governments overruling FCC guidelines calls into question the use-value of the Cable Act in strengthening localism. Beneficiaries from these rulings may argue it is indeed an exercise of localism to self-govern at the cost of federal rules.

In addition to local laws side-stepping FCC regulation, cable companies are doing the same. Current lack of federal control over the operations of private enterprise creates room for cable providers to place public channels on the margins of their services in certain areas. Waldman (2011) notes that AT\&T has placed all PEG programming on a single channel that requires the viewer to make their way through multiple drop down menus to select the channel of their choosing. Rather than a designated public channel, 
that same content resides in the depths of several digital windows the viewer must navigate. Not only does this require a digital literacy some may not possess, but many community members still lack the equipment such as a cable box to view digital channels. At the same time cable companies are within the bounds of communication law and may place channels where they wish so long as they are still providing local content. From the business point of view companies should have the freedom to arrange their channels in a way that fulfills their fiduciary obligations to investors.

Cable Franchise Fees have also historically yielded public and government benefits. In New York City, Franchise Fees were totaled at 140 million dollars during 2010. Franchise Fees have also been used to direct even more capital into PEG facilities (Waldman, 2011). Suggesting that if used to its maximum benefit Franchise Fees could fund PEG facilities to their full capacities virtually indefinitely. Local governments may use the funds however they see necessary which provides budgetary room for special projects not covered by federal or state support. Given the absence of limits on how Franchise Fees may be disbursed, a city can use this for its own development, like improving bridges. Or perhaps for an emergency fund. In the broadest sense Franchise Fees are important because they can, and have, financed the special and unique interests of the local, centralizing political power closer to home, and satisfying Mill's (1865) requirement for democracies to widely scatter governing power to the proximal, overall augmenting the propensity for self-determination.

The major criticism of the Franchise Fee rests in its present day lack of accountability, because it is illegal to regulate how Cable Franchise Fee revenue is spent, 
the money often disappears into the general treasury with no evidence of where it was dispersed to after the initial transfer to the general fund. This complaint may be magnified by the realization all cable Franchise Fees are paid for by the consumer. Ideally, those funds should be reinvested for the public good as it is an effective tax on the public. Franchise Fee revenue has the potential to greatly improve cities, but it is often uncertain whether or not that improvement is being actualized because disbursements from such revenue are only reported as disbursements from the general fund. In some cases where it could be determined the degree to which Franchise Fee revenue is allocated toward public spending the amount is relatively small. Waldman (2011), cites an email from Jennifer Gilomen, the Director Public Media Strategies at Bay Area Video Coalition during 2011, describing that "in San Francisco, only about 8 percent, of the roughly $\$ 10$ million to $\$ 12$ million cable operators pay in franchise fees, goes to public access each year" (p.173). Thus, analysts are irresolute that the money the public is being charged is returned to them.

Looking forward, the fate of both fees is in doubt as cord-cutting grows more common. Subscription services such as Netflix and Hulu are increasingly making cable subscriptions irrelevant. As a result the changing media landscape is constricting a major source of funding for local media by limiting Franchise and PEG Fee revenue because both fees are entirely composed of money paid by the cable subscriber. The contemporary composition of the media marketplace encourages a re-evaluation of the relevance of these fees, and if they prove to remain useful, begs for a discussion on how to best modernize their operation. 
Additionally, as broadband becomes more widely available critics of PEG and Franchise Fees might propose that the internet alone provides the same advantages: a forum for individual expression, diversity of content, and access to noncommercial opinions in place of public access programs. The need for the fees may be decreased by major information sharing web platforms like YouTube and Facebook. However, just as wealth and ownership concentration affects what might be broadcast on television, it also determines who has access to the internet and digital content writ large. Though the internet may provide similar benefits to public television and PEG facilities, access to broadband is still disproportionate among many populations in the US (FCC, 2015). Further, PEG funds have been utilized to subsidize internet access among students and rural populations (Waldman, 2011). Therefore, even if the evolution of the media landscape outpaces traditional platforms like public television there still may be use and need for PEG and Franchise finances.

\section{Research Questions}

Supporters of PEG and Franchise Fees conclude that they provide multidimensional benefits, but a dearth of financial evidence exists to determine whether or not they really live up to these aspirations. Little evidence documents that fees are being spent meaningfully, and in a manner consistent with FCC law. Though, the search for this evidence should prioritize a secondary, more specific question that asks what benefits the members of a public see returned to them when they pay these fees each month. Further, the potential versus actualized benefits of each fee should be grounded in the context of the changing media environment. If cities are not allocating revenue earned 
from PEG and Franchise Fees to public media, or are only doing so to a minimal degree, then there may not be unique advantages to them when compared to the benefits and rise of internet platforms. As we transition to the digital era this research seeks to contribute to a larger discussion on the modern day purpose and function of the PEG and Franchise Fee by gathering the foundational data to answer the aforementioned questions. Identifying the contemporary function of the fees is a pre-requisite to determining whether or not the FCC principle of localism is being met, and if the form that localism takes is mobilized for the public good.

RQ1: If Franchise Fees are being collected, how much did a city earn from them?

RQ2: Where is Franchise Fee revenue being spent?

Franchise Fees collect billions of dollars from millions of households, but there is alarmingly little clarity about how those funds are spent. Tracking the collection and disbursement of revenue is an essential component of good governance because it holds leaders accountable for the policies that they are obligated to enforce. In other words, prior to making a demand that a public policy should be strengthened it is necessary to prove that it is not currently being enacted properly. The prerequisite to proper enforcement of policy is sound data, which motivates my following research questions.

RQ3: If PEG funds are being collected, how much did a city earn from them?

RQ4: Are PEG funds spent in a way consistent with FCC mandates?

Put simply, this will be the first data collection of its kind and it comes at a crucial point in the fight for local media. Local newspapers are declining at unprecedented rates (Shaker, 2014). Local media outlets are vanishing and along with them their unique 
social and political benefits. PEG and Franchise Fees collect large amounts of funds each year with the purpose of supporting local media. If funds are being misallocated to the extent that critics suggest, then cities are squandering the fruits of a key policy that may guarantee some semblance of local media subsisting in the future, and in turn may be wasting the public's money as they are the people supplying the revenue. 


\section{CHAPTER 3: METHOD}

The audit to follow combines budgetary reports from the twenty largest U.S. cities by population as of 2013 . These cities were selected because more populated cities are where franchise agreements affect the largest number of people. The analyzed budgets are from the most recent complete fiscal year (FY 2015-2016) excluding the budgets from Charlotte, North Carolina and Indianapolis, Indiana for which proposed budgets for the operating fiscal year (FY 2016-2017) were used because the most recently completed fiscal years of the two cities were not available. Budgets were collected from official government websites from each respective city. Each budget was inspected to determine whether or not the city collected PEG and Franchises Fees and, if so, the total reported (FY 15-16) or projected (FY 16-17) revenue from those fees and financial disbursements to cable and PEG recipients were identified and reported. This information was located by using the following search terms within each document. In order of use: "cable", "PEG", "franchise", "telecommunication", "tv", and "television." If the search terms did not locate relevant information, budgets were read page by page to discover the pertinent information.

If the budget for a given city did not report collecting either fee, the LexisNexis database was employed to find evidence which confirmed whether or not the city collected the fees. This secondary search was used for data anchoring purposes. Even if LexisNexis documents did not include budgetary totals, they documented whether or not those totals were supposed to be included in the budgetary report and were thus missing or if they were absent because the city elected not to collect the fees. LexisNexis search 
terms included the city in question and PEG or Franchise Fee, e.g. "Austin AND PEG” or "Dallas AND Franchise." LexisNexis includes case law, news articles, and state and federal cases. In addition, the largest locally funded public television station in the city was identified. This search excluded channels that exist under the umbrella of The Public Broadcasting Service. If more data was needed to confirm that a city did or did not collect either fee, financial records of public stations were reviewed in an attempt to determine if they received funding from either PEG or Franchise Fees disbursements. Last, each city budget was read page-by-page to determine where revenue from both fees was expended, if at all. 
INVESTIGATING CABLE

CHAPTER 4: RESULTS

Table 1

Collection of Fees

\begin{tabular}{llll}
\hline City & PEG fee Collection? & $\begin{array}{l}\text { Franchise Fee } \\
\text { Collection? }\end{array}$ & Major public channel \\
\hline Austin & Yes & Yes & ATXN \\
Charlotte & No & Yes & Access 21 \\
Chicago & No & Yes & CAN TV \\
Columbus & No & Yes & CTV \\
Dallas & No & Yes & None as of 2009 \\
Detroit & Yes & Yes & Unknown \\
El Paso & Yes & Yes & KCOS TV \\
Fort Worth & Yes & Yes & FWTV \\
Houston & Yes & Yes & HTV \\
Indianapolis & Yes & Yes & Ch. 16 \\
Jacksonville & No & Yes & Ch. 99 \\
Los Angeles & Yes & Yes & LA 36 \\
New York & Yes & Yes & DCTV \\
Philadelphia & Yes & Yes & PHL GOV TV \\
Phoenix & No & Yes & PHX TV \\
San Antonio & No & Yes & PATV \\
San Diego & Yes & Yes & CTN \\
San Francisco & No & Yes & SF Commons \\
San Jose & Yes & Yes & Cera TV \\
Seattle & Yes & Yes & Channel 77/23 \\
\hline Chatles & Pos & PE Fe, and Access 21 repots the fung Public
\end{tabular}

Charlotte reports a unique "Carrier Fee" but no PEG Fee, and Access 21 reports the funding as Public Access Fees.

Jacksonville's public channel halted public programming in 2015 per a renewed agreement with Comcast, and now only provides government programming.

Detroit, Jacksonville, Phoenix, San Antonio, and San Francisco do not report collecting a PEG Fee, but fund the public access channel listed.

Table 1 documents whether or not the city in question collects a PEG Fee and a

Franchise Fee. Twelve of the twenty cities shown in Table 1 report collecting a PEG Fee via their own budgetary reports, or documented evidence found through LexisNexis.

Eight cities were confirmed not to collect PEG Fees.

All cities were determined to collect a Franchise Fee. Because each fee is dependent on the franchising agreement the cable company holds with each franchising 
authority in a given city, the absence of either fee in a budget is likely the result of the city’s choice not to levy either fee on cable carriers (Cable Act §611(b) [531(b)]).

However, cities which are confirmed to collect either fee in Table 1 should have revenue and expenditures to report from those fees in their budgets. Table 2 will reveal sums of these expenditures, and Table 3 will categorize those sums.

Each city which collects a PEG Fee also has a public access channel. The funded stations are primarily a mix between government programming and broadcasts of content created by the public, and are unique to each city. Data shows that the PEG Fee is not the only resource cities are using to finance the operations of the public stations. In each city researched a cable subscription holder will have access to a public station. Cities are using their right to mandate that carriers reserve space for the broadcast of public programming. 
INVESTIGATING CABLE

Table 2

Cable Related City Finances

\begin{tabular}{lllll}
\hline City & $\begin{array}{l}\text { Franchise Fee } \\
\text { Revenue }\end{array}$ & PEG Fee Revenue & $\begin{array}{l}\text { Cable \& PEG } \\
\text { Expenditures }\end{array}$ & $\begin{array}{l}\text { Revenue } \\
\text { Remaining } \\
\text { after PEG \& } \\
\text { Cable } \\
\text { Expenditures }\end{array}$ \\
\hline Austin & $\$ 37,700,000$ & $\$ 1,900,000$ & $\$ 5,474,177$ & $\$ 34,125,823$ \\
Charlotte* & $\$ 7,959,632$ & No Fee & $\$ 3,449,234$ & $\$ 4,510,398$ \\
Chicago & $\$ 29,200,000$ & No Fee & $\$ 656,297$ & $\$ 28,543,730$ \\
Columbus & $\$ 9,600,000$ & No Fee & $\$ 1,055,233$ & $\$ 8,544,767$ \\
Dallas & $\$ 27,394,587$ & No Fee & $\$ 2,567,235$ & $\$ 24,827,352$ \\
Detroit* & $\$ 7,800,000$ & $\$ 500,000$ & $\$ 1,989,998$ & $\$ 6,310,002$ \\
El Paso* & $\$ 8,767,956$ & Not reported & $\$ 964,887$ & $\$ 7,803,069$ \\
Fort Worth & $\$ 6,680,684$ & $\$ 1,200,000$ & $\$ 1,200,000$ & $\$ 6,680,684$ \\
Houston & $\$ 23,900,000$ & $\$ 5,286,382$ & $\$ 4,917,557$ & $\$ 23,672,343$ \\
Indianapolis & Not reported & $\$ 556,193$ & $\$ 556,193$ & 0 \\
Jacksonville* & $\$ 35,300,000$ & No Fee & Not reported & NA \\
Los Angeles* & $\$ 20,403,181$ & $\$ 7,769,718$ & $\$ 34,959,299$ & $\$ 5,223,002$ \\
New York* & $\$ 160,847,000$ & Not reported & $\$ 36,241,332$ & $\$ 124,605,668$ \\
Philadelphia & $\$ 21,442,000$ & Not reported & Not reported & NA \\
Phoenix* & $\$ 9,500,000$ & No Fee & $\$ 6,430,349$ & $\$ 3,069,651$ \\
San Antonio & $\$ 30,700,000$ & No Fee & $\$ 212,410$ & $\$ 30,487,590$ \\
San Diego & $\$ 18,600,000$ & Not reported & $\$ 5,263,052$ & $\$ 13,336,948$ \\
San Francisco* & $\$ 3,090,700$ & No Fee & Not reported & NA \\
San Jose & $\$ 9,900,000$ & $\$ 2,000,000$ & $\$ 2,243,396$ & $\$ 9,656,604$ \\
Seattle & $\$ 8,645,104$ & Not reported & $\$ 8,417,829$ & $\$ 227,275$ \\
\hline Chatete & & &
\end{tabular}

Charlotte Reports an additional revenue of $\$ 100,000$ as a "carrier fee" (Appendix B).

Detroit reports \$2.8 million of Franchise Revenue coming from "Maintenance Fees" (Appendix F).

El Paso reported their PEG revenue as an aggregate with Franchise Fees and thus it is indiscernible

(Appendix G).

Jacksonville's Franchise Revenue is an aggregate score of all Franchise Fees the city collects in addition to cable (Appendix K).

Los Angeles adds $\$ 11,859,422$ unexpended available revenue from previous year and $\$ 150,000$ from other receipts to the revenue reported here (Appendix L).

New York records their Franchise Fee revenues as an aggregate with "permits and privileges"

(Appendix M).

Phoenix's expenditures exclude a $\$ 5,362,000$ transfer to the general fund (Appendix O).

The number listed for San Francisco's Franchise Fee Revenue was reported in budget as "licenses and fines" (Appendix R).

San Francisco lists one disbursement to the office in charge of regulating cable at $\$ 97,292,347$ which does many things including architecture security, public safety, administration and finance, service delivery and finally public TV. This leaves us no way to discern the amount of cable related expenses (Appendix R). 
Table 2 displays the revenue each city reported from the collection of PEG and Franchise Fees and the expenditures that were dedicated to the funding of the offices that facilitate the collection and disbursements of such funds, costs of PEG programming, and/or miscellaneous expenditures that were funded by either fee's revenue. The remaining revenue after expenditures is the difference between the sum of revenue and sum of expenditures for a city. This revenue may be sent to the general fund or saved for the coming fiscal year's cable costs.

When PEG Fees are collected, the total revenue a city earned from that fee in particular is often not transparent. Despite evidence of a PEG Fee being collected in El Paso, Philadelphia, San Diego, and Seattle, PEG Fee revenue is unavailable in the budget details. These cities could have labeled the PEG Fee with a different name, or reported PEG revenue in the aggregate with other non-cable related franchises, licenses, and permits. New York City, for example, reported cable fees in the aggregate. Thus, in five of twelve cities collecting the PEG Fee the exact revenue generated by the fee is unknown. An unknown amount of total revenue in these cities conceals the information that would reveal whether or not PEG funds were spent in line with federal mandates. In Austin, Indianapolis, Los Angeles, and San Jose, spending on PEG related costs exceeds the total revenue collected on PEG Fees. Fort Worth and Houston show PEG expenditures that total less than their total amount of revenue in the year analyzed. Per federal law, cities are not required to spend all revenue in a given year (Cable Act $\S 611(b))$. Finally, Detroit reported a balanced PEG budget. 
Franchise Fee revenue is reported in every city except Indianapolis ${ }^{2}$. When Franchise Fee revenue is reported, it is clear cities are receiving millions per year in revenue. However, the total revenue earned from this program remains ambiguous in several places. Jacksonville, New York City, and San Francisco report their total revenue earned from the Franchise Fee as an aggregate with other programs and fees. For example, Jacksonville reports their cable revenue as part of one large line-item that sums earnings from every municipal franchise in the city such as natural gas, sewer services, and telephone (Appendix K). It can however be determined that the financing of this revenue comes to bare heavily on the public. According to an Austin advertising agency there are 542,192 cable households in the city as of the last fiscal quarter of 2016 (Frink, 2017). The total amount of Franchise Fee revenue from Austin divided by cable subscribing households reveals that each family paid the city approximately ${ }^{3} \$ 69.50$ in Franchise Fee charges alone. The same households paid \$3.50 in PEG Fees. In total Austin cable subscribers $\$ 73$ in 2016 in cable fees.

It is difficult to determine where Franchise Fee revenue goes after it is collected. After the administrative, infrastructure, and PEG related costs of cable are funded, every city excluding Indianapolis, Jacksonville, Philadelphia, and San Francisco, yield excess revenue. It appears that some Franchise revenue is being allocated to PEG resources in Austin, Indianapolis, Los Angeles, and San Jose. Other funds are largely going to administrative costs, and occasionally going toward road and infrastructure updates due

\footnotetext{
${ }^{2}$ This is likely due to the fact the budget analyzed for this city is a projected budget of FY 2016-17.

${ }^{3}$ It is likely there were slightly more or less cable subscribers during the last quarter of 2016 when the budget was completed.
} 
to the physical wear and tear on the public right of ways. Most Franchise Fee funds are unaccounted for. 
INVESTIGATING CABLE

Table 3

Expenditures per category from cable revenue

\begin{tabular}{llllll}
\hline City & $\begin{array}{l}\text { Administrative } \\
\text { expenditures }\end{array}$ & $\begin{array}{l}\text { Infrastructure } \\
\text { expenditures }\end{array}$ & $\begin{array}{l}\text { PEG related } \\
\text { expenditures }\end{array}$ & $\begin{array}{l}\text { Other } \\
\text { expenditures }\end{array}$ & $\begin{array}{l}\text { Cable } \\
\text { expenditures }\end{array}$ \\
\hline Austin & $\$ 2,496,739$ & $\$ 0$ & $\$ 2,977,438$ & $\$ 0$ & $\$ 5,474,177$ \\
Charlotte & $\$ 0$ & $\$ 0$ & $\$ 3,449,234$ & $\$ 0$ & $\$ 3,449,234$ \\
Chicago & $\$ 0$ & $\$ 0$ & $\$ 656,297$ & $\$ 0$ & $\$ 656,297$ \\
Columbus & $\$ 0$ & $\$ 0$ & $\$ 1,055,233$ & $\$ 0$ & $\$ 1,055,233$ \\
Dallas & $\$ 1,865,247$ & $\$ 701,988$ & $\$ 0$ & $\$ 0$ & $\$ 2,567,235$ \\
Detroit & $\$ 1,489,998$ & $\$ 0$ & $\$ 500,000$ & $\$ 0$ & $\$ 1,989,998$ \\
El Paso & $\$ 200$ & $\$ 0$ & $\$ 964,687$ & $\$ 0$ & $\$ 964,887$ \\
Fort Worth & $\$ 0$ & $\$ 0$ & $\$ 300,000$ & $\$ 900,000$ & $\$ 1,200,000$ \\
Houston & $\$ 2,347,250$ & $\$ 0$ & $\$ 2,570,307$ & $\$ 0$ & $\$ 4,917,557$ \\
Indianapolis & $\$ 0$ & $\$ 0$ & $\$ 556,193$ & $\$ 0$ & $\$ 556,193$ \\
Jacksonville & Unknown & Unknown & Unknown & Unknown & Not reported \\
Los Angeles & $\$ 11,223,166$ & $\$ 0$ & $\$ 20,015,751$ & $\$ 8,943,404$ & $\$ 34,959,299$ \\
New York & $\$ 36,241,332$ & $\$ 0$ & $\$ 0$ & $\$ 0$ & $\$ 36,241,332$ \\
Philadelphia & Unknown & Unknown & Unknown & Unknown & Not reported \\
Phoenix & $\$ 2,368,000$ & $\$ 1,770,000$ & $\$ 2,292,349$ & $\$ 5,362,000$ & $\$ 6,430,349$ \\
San Antonio & $\$ 0$ & $\$ 0$ & $\$ 212,410$ & $\$ 0$ & $\$ 212,410$ \\
San Diego & $\$ 3,563,052$ & $\$ 0$ & $\$ 1,700,000$ & $\$ 0$ & $\$ 5,263,052$ \\
San Francisco & $\$ 97,292,347$ & $\$ 0$ & $\$ 0$ & $\$ 0$ & Not reported \\
San Jose & $\$ 0$ & $\$ 0$ & $\$ 3,308,792$ & $\$ 0$ & $\$ 2,243,396$ \\
Seattle & $\$ 4,566,090$ & $\$ 0$ & $\$ 3,851,739$ & $\$ 0$ & $\$ 8,417,829$ \\
\hline
\end{tabular}

Table 3 categorizes the expenditures of each city to determine how revenue from cable fees is spent. Administrative expenditures include contracting fees, utility management, departmental services charged with the maintenance and operation of cable television, and transfers to the general fund. Infrastructure expenditures include the cutting and repair of streets and cables. PEG expenditures include costs of public, educational, and government programing such as video equipment, programming, broadcasting, and in the case of Sand Diego library improvement (Appendix Q). Other expenditures are detailed in Appendices A-R, and primarily include transfers to other administrative appropriations and offices that deal with cable in addition to many other 
services such information security, municipal telecommunication networks, and technology and transportation infrastructure.

In summary, cities can be divided into four groups. First, those that do not appear to collect a PEG Fee (8/20 cities). Of this group, no city reports PEG revenue. Second, those that do appear to collect a PEG Fee (12/20 cities). Of this group, five cities (El Paso, New York, Philadelphia, San Diego, and Seattle) do not report revenue. The seven that report revenue allocate funding largely to PEG programing and facilities, and the administrative expenditures accompanied by those projects. Cities are generally not financing PEG related infrastructure projects such as new facilities. The third group is composed of cities that collect a Franchise Fee (20/20 cities). Of this group nineteen cities report revenue. Across the board, cities are receiving large amounts of revenue from levying Franchise Fees. The final group are cities that do not appear to report Franchise Fee revenue (1/20). There is evidence to suggest this city collects the fee, but did not report it in the budget analyzed. This city (Indianapolis) funds public access television and PEG facilities via a PEG Fee. 


\section{CHAPTER 5: DISCUSSION}

Perhaps the most compelling reason the fees' revenue should be administered to the public's benefit is that all revenue from both fees originates from additional charges added to each subscriber's cable bill. In other words, the totality of PEG and Franchise Fee revenue is funded solely by the millions of homes throughout the United States with a cable subscription. Thus, when comparing the potential value or benefits of these programs to their actualized value; actualized value should be considered on a scale of what benefits are realized for the these citizens and their communities.

This work has explored the potential value of both fees by analyzing the past, present, and predicated future contributions to the public. In the context of decaying local media, PEG and Franchise revenue function as an important tool, creating a fixture of locally operated media in many cities. The resources provided by the fees are a means to political efficacy, strengthened community ties, and multimedia resources in schools and other government institutions. The data affirms and complicates those theories. In some instances revenue from the fees is directed in plentiful amounts toward public goods. In other cases prospective millions of dollars are unaccounted for, calling into question the validity and effectiveness of PEG and Franchise Fees.

Franchise Fees. It is clear cities are collecting millions in Franchise Fee revenue. It can hardly be determined where Franchise Fee-revenue is allocated. However, the data does show it often funds the remaining costs of public programming and the capital costs of those facilities when the PEG Fee does not fully fund their operations, or exist in the city. In every city there are millions of remaining dollars that could be apportioned to 
additional and diverse programming, media upgrades in schools and government offices, and facilities where the public may go and create their own broadcasts.

It cannot be determined how excess Franchise Fee revenue was used in any city outside of its allocation to the general fund. This is problematic because channeling a stream of revenue through the general fund prior to expenditures obscures the source of revenue being spent and makes the process less transparent. Without line-items for the differences between revenue from fees and expenditures it is not clear where this money is going. It could be unallocated funds are either sent to the general fund, saved for allocation toward cable costs for the coming year, or spent in unrelated areas. All of the above options are not the prime strategy for actualizing the full value of the fee for the public for three reasons. First, additional funds can nearly always be spent on public programming facilities and materials, media in education institutions, modernizing government telecommunication networks, and/or making more accessible broadcasts of government proceedings. Second, without making distinctions between different sources of revenue there can be no program evaluation. Citizens cannot determine how their money gets used and thus are denied the ability to engage in planning that optimizes the outcome of those funds because measurements of their use-value cannot be taken. Finally, a lack of clarity as to where franchise revenue is spent discourages community participation in the politics of resource allocation because the information is inaccessible. Community members often have the best insight on where local needs exist, and therefore excluding the private citizen from this process denies the optimal usage of the Franchise Fee. 
If cities are funding public television via their Franchise Fee, then it begs an additional question: why not also levy a PEG fee? Evidence that the cities above are funding public access television is proof positive that the reasoning for not levying the fee is not a lack of desire to fund local programming, but a lack of political will in that direction. This could also be due to the results of negotiations between cities and cable companies who would seek to avoid those fees for the sake of providing competitive pricing on their services. Additionally, the choice to fund public television from a Franchise Fee alone may allow cities to dodge accountability for two reasons. First, it is money sent directly to the general fund in most cases, making it untraceable. Second, there are no limitations on how it can be spent. This could allow a city to fund a single station at minimal levels while distributing remaining revenue to projects that are of lesser benefit to the public, or no benefit at all. In the opposite direction, one benefit of funding public television through the Franchise Fee alone is it lowers the tax on the public. Franchise Fees are capped, whereas levying a PEG Fee would require a fee for the cable customer greater than $5 \%$ of the bill.

In sum, portions of the Franchise Fee are being used in the interest of the public good. A large portion of cities allocate some funding from this fee to public access programing, but when comparing this to the millions of additional revenue eared across cities, it has the potential to do more. It remains unknown where excess funding is directed. Increased transparency would ensure resources are handled in a manner consistent with directly benefitting the local. For now, interested citizens cannot discern how Franchise Fee revenue (their money) is spent in its entirety. 
PEG Fees. This project sought to determine whether or not cities are collecting PEG Fees, the amount of revenue those collections may consist of, and how that revenue was spent. The majority of cities researched are collecting PEG Fees at levels ranging from half a million to several million dollars. In cities where total PEG revenue is explicitly reported, expenditures appear to be consistent with FCC law. Of the cities collecting PEG Fees, many (7/12) are allocating their revenue toward PEG resources, cultivating local information networks that meet public needs. For example, Austin collected $\$ 1.9$ million from PEG revenue, and spent a total of $\$ 2,977,438$ on PEG related expenses. $\$ 1,102,438$ was sent directly to the public access station, and $\$ 1,875,000$ was spent on other PEG related capital costs such as facilities and equipment. As Austin spent an additional million on PEG related costs than their total PEG revenue it appears that the city spent PEG revenue within the confines of FCC regulation (Appendix A).

Of concern are the others, $(5 / 12)$ that collect a PEG Fee, but do not report their revenue. In these cities, the PEG Fee is a tax on cable subscribers without accountability. It seems then, a demand for greater transparency among both fees is needed to address the disparity between the actual and theoretical value of these polices.

Finally, when analyzing the expenditures from each city, many line items receipts remain ambiguous. Often those disbursements listed as administrative costs are spent on allocations to an office that performs duties outside of cable and PEG programing making it uncertain how revenue is being spent (see Appendices A-T). For example, in San Francisco $\$ 97,292,347$ is given to a Department of Technology responsible for the maintenance of the city's telecommunication networks, architecture safety, and some 
financing. A budget viewer cannot further parse out how funds were distributed within the department. Thus a member of the locale cannot ascertain the degree to which public television was funded compared to other expenditures, and whether or not it was funded within the confines of FCC regulation. Part of a renewed demand for transparency among PEG and Franchise revenue then, should also include a recommendation that expenditures be detailed rather than categorized. This is the difference between allocating funds to "cable costs" and instead distinguishing the cable costs as "PEG facility capital costs", "road repair", and "audio visual equipment." Detail is a required component of transparency.

\section{Reccomendations}

Several recommendations may help move cities toward a more transparent and effective use of the fees. First, the FCC should mandate that cities levy a PEG Fee if they levy a Franchise Fee. This would ensure the public is being repaid for their contributions to cable companies, the right of way has the necessary upkeep, and a portion of television remains public. Cities will not end the collection of Franchise Fees as it makes up significant portions of their budgets. Tethering the PEG Fee to any cable franchising agreement generates a lifeline for local media. Of course carriers would pass along the additional charges from the new contracts to the public. Because this effectively raises the price of a monthly cable bill carriers will be inclined to oppose a new agreement of this character. This will force cities to negotiate more narrowly with carriers or lower their Franchise Fee by the percentage of the PEG Fee to keep costs a constant. As it appears in the data most every city enjoys the discretionary revenue from Franchise Fees. 
It is reasonable they will be hard pressed to forego this and instead will demand a PEG Fee on top of existing Franchise Fees or in place of some amount of the Franchise Fee.

Second, the FCC should mandate that revenue from Franchise and PEG Fees be reported individually in the city budget. This creates a central location where the public can observe how much was earned in a given year. Individual reporting would certify that cities do not report revenue with other income in the aggregate, masking just how much was made in a fiscal year.

Last, all expenditures from either revenue source must be line-itemed in the city budget. This would necessitate that each fee be housed in a different account separate from the general fund. Cities may still spend the Franchise Fee at their own discretion, but now with a publically accessible record. This would allow the public to determine if the funds are being used for the good of their localities. Public record of the spending can function as a means of political agency for community members.

\section{Other Considerations}

A prima facie tension is present in this research. While the literature review takes an avid position on the importance of the proximal, the small, and broadly the local- data for this project was extracted from the twenty of the largest metropolitan areas in the United States. This may seem to undermine claims being made about the importance of more narrow localities. To clarify, heterogeneous communities and localities compose the fabric of larger cities. PEG programming functions as insurance that the smaller nonEnglish-speaking-communities have access to public programming when ownership and programming diversity is on the decline. Hence while the criticism that more complete 
research would also collect data from smaller locales is fair, small locales were considered from the onset.

Future research should not only consider analyzing cities with a difference in size, but should consider performing a longitudinal observation. Authors like Waldman (2011) and Shaker (2014) have described the precarious position of local media, and while previous literature has illustrated several ways the fees may address this concern, its cross sectional data cannot make claims about trends. Additional work on this topic might use this data compared to another year or set of years to establish a relationship or lack thereof between the fees and the strength of local media, and how it fits within an evolving media environment. Longitudinal research could also offer the capacity to discover the predicated future of PEG programming years after Waldman (2011) foresaw a grim future.

One limitation to consider with the above data is a potential discrepancy in time. City and state policies can change quickly. There is a risk that cities that do not report fee revenue, but reported collecting either fee in a LexisNexis document could have revised their telecommunication policies between the dates of the evidence publication and time of this research. If this were the case however, then the LexisNexis search engine should have provided the legal documents indicating a change in policy.

Some may consider evolving communication infrastructure and markets to mitigate the importance of public programming. Such arguments may suggest that the internet and rise of digital television provide space for public creation and broadcast, and better resolve the concerns about the democratic empowerment of the local. While the 
changing media landscape certainly includes some public benefits similar to PEG programs and facilities, it cannot act as a total replacement. Access to internet is not equal amongst all populations and is instead stratified along the lines of race and class (FCC, 2015). The rise of digital content instead suggests that PEG and Franchise Fees can be utilized to modernize communication infrastructure for those subject to the harshness of the digital divide. In some cases cities have subsidized internet using PEG fees (Waldman, 2011). The changing media landscape may illustrate the need to revisit the way cable contracts are created, and begin a conversation about the desirability of, and method by which, the FCC might integrate similar policies to Franchise and PEG fees into digital television services.

Finally, perhaps some concern can be given to the opportunity cost of focusing on PEG programming instead of conducting bureaucratic resources in other directions that are of more or equal importance. While this could be the case, PEG programming is a matter of community building. Equal access to local political information, user created content, and media made specifically for a given locale defines a public and motivates dialogue on the challenges facing it. Community building creates an engaged public which is critical to diagnosing and resolving other social ills because it provides the information and organization imperative to doing both. 


\section{CHAPTER 6: CONCLUSION}

Franchise and PEG fees may provide a myriad of benefits. For some cities they are a wellspring that delivers local news and political information, for others the source of computers and broadband in public schools. The fees provide an outlet for the public, a space where they may broadcast their creations and opinions without consideration of private ownership. The commonality among the benefits of these programs is in the spirit of providing the means to create and consume media regardless of wealth or language. In contrast to this, $90 \%$ of American media organizations were controlled by six companies in 2011, compared to fifty companies owning the same amount in 1983 (Lutz, 2012). Of those six media giants 232 executives may determine the possible media choices of 277 million Americans (Lutz, 2012).

As the means to create and distribute mass media become increasingly concentrated, academic and political focus should continue to review current media policy, making certain regulatory strategies are protecting the public and safeguarding democratic media from unfettered corporate competition. In the most material sense, when revenue from these fees are not reinvested in the public, the city is lessening access to avenues of speech, creativity, and political discourse for its citizens. Refusing to levy a fee gives cable companies a break and effectively loosens restrictions on ownership concentration. If local media is replaced overtime by the programs of media giants then many lose access to their publics, their proximal political spheres, and collectively the democratic citizen is left with a withered version of the fourth estate check on political corruption, especially at the local level (Baker, 2007). 
The local cable subscriber pays out-of-pocket each month for the benefits of local media, but the value of that programming has yet to be determined when compared to the amount each household pays their city annually. Additionally, there are massive quantities of left-over funds that could, and should, be directed toward local media and public projects. Situated in a time of cord-cutting, lack of clarity on the public benefits of the fees does not function well to preserve their existence as many consider going digital. The trends of internet-tv subscriptions, and decline in cable subscriptions suggests that Franchise and PEG Fee revenue will also decline as their source of funding is truncated. Thus there are many oncoming questions to be answered about how local television will be subsidized in the future. The internet may provide similar benefits to the establishments paid for by the fees, but it's potential to completely replace the local information needs of communities remains doubtful (Shaker, 2014). If public programming is to be preserved and with it its contribution to localism, then greater oversight is needed to certify that those cities collecting fees from the public report their revenue, and that such revenue is re-invested in the public as it is primarily their money that has funded local media to this point, and will most likely continue to be. 
References

Alliance for Community Media v. FCC. (1995) 56 F.3d 105 (D.C. Cir.).

Baker, C. E. (2007). Media concentration and democracy: Why ownership matters. Cambridge University Press.

Barthell, M. (2016). Five take-aways about the state of the news media in 2016. Pew Research. http://www.pewresearch.org/fact-tank/2016/06/15/state-of-the-newsmedia-2016-key-takeaways/.

Boleman, T. (2008). Federal limitation of PEG Fees to capital costs only. Mackinac Center for Public Policy. https://www.mackinac.org/10130\#_ftn*.

Briffault, R. (1990). Our Localism: Part II--Localism and Legal Theory. Columbia Law Review, 90(2), 346-454.

City and County of San Francisco (2009) ; The Digital Infrastructure and Video Competition Act of 2006. In Waldman, S. (2011). Information needs of communities: The changing media landscape in a broadband age. DIANE Publishing.

de Tocqueville, A. (1899). Democracy in America: By Alexis de Tocqueville. PF Collier \& son.

Federal Communications Commission. (2017). Broadcast Station Totals. https://www.fcc.gov/media/broadcast-station-totals.

Federal Communications Commission. (2015). 2015 Broadband Report. https://www.fcc.gov/reports-research/reports/broadband-progress-reports/2015broadband-progress-report. 
Friedland, L. A., \& McLeod, J. M. (1999). Community integration and mass media: A reconsideration. Mass media, social control, and social change: A macrosocial perspective, 197-226.

Frink Advertising. (2017). Market overview Austin, TX.

https://www.frinkadvertising.com/cable-television-advertising-market-overviewaustin/.

Horriggan, J., \& Duggan, M. (2015) One-in-seven Americans are cord-cutters. Pew Research Center. http://www.pewinternet.org/2015/12/21/4-one-in-sevenamericans-are-television-cord-cutters/

Kaniss, P. (1997). Making local news. Chicago, IL: University of Chicago Press.

Linder, L. R. (1999). Public access television: America's electronic soapbox. Greenwood Publishing Group.

Lutz, A. (2012). These six corporations control $90 \%$ of the media. Business Insider. http://www.businessinsider.com/these-6-corporations-control-90-of-the-media-inamerica-2012-6.

Mill, J. S. (1865). Considerations on representative government. Longmans, Green, and Company.

Mondak, J. J. (1995). Nothing to read: Newspapers and elections in a social experiment. Ann Arbor, MI: University of Michigan Press.

Moy, P., McCluskey, M. R., McCoy, K., \& Spratt, M. A. (2004). Political correlates of local news media use. Journal of Communication, 54(3), 532-546. 
INVESTIGATING CABLE

Napoli, P. M. (2001). Foundations of communications policy: Principles and process in the regulation of electronic media. Hampton Pr.

Pressman, A. (2016). More than one in five households has dumped cable goliath. Fortune. http://fortune.com/2016/04/05/household-cable-cord-cutters/.

Rogoway, M. (2016). Lawsuit claims Portland, suburbs misspent \$14 million in cable fees. The Oregonian.http://www.oregonlive.com/siliconforest/index.ssf/2016/11/lawsuit_claims_portland_suburb.html.

Rogoway, M. (2017). Judge tosses out suit challenging Portland cable TV fees. The Oregonian. http://www.oregonlive.com/siliconforest/index.ssf/2017/07/post_4.html\#incart_std.

Schulhofer-Wohl, S., \& Garrido, M. (2011). Do newspapers matter? Short-run and longrun evidence from the closure of the Cincinnati Post. Retrieved from: https://www.minneapolisfed.org/research/wp/wp686.pdf

Shaker, L. (2014). Dead newspapers and citizens' civic engagement. Political Communication, 31(1), 131-148.

Shaker, L. (2009). Citizens' local political knowledge and the role of media access. Journalism \& Mass Communication Quarterly, 86(4), 809-826.

Starr, P. (2011). Goodbye to the age of newspapers (hello to a new era of corruption): Why American politics and society are about to be changed for the worse. In R. W. McChesney \& V. Pickard (Eds.), Will the last reporter please turn out the lights: The collapse of journalism and what can be done to fix it (pp. 18-37). New York, NY: New Press 
Sixth Circuit Court, US. (2008). On Petition for Review of an Order of the Federal Communications Commission. No. 05-311. http://www.opn.ca6.uscourts.gov/opinions.pdf/08a0230p-06.pdf.

Tarde, G. (1903). The laws of imitation. New York, NY: H. Holt \& Company. Telecommunications, Title 47 U.S. Code $§ 542$. Accessed from https://www.law.cornell.edu/uscode/text/47/542. Retrieved on 4/17/17. U.S. House, 104th Congress, Committee of Conference. Telecommunications Act of 1996 (H. Rept. 104-458, pt. 2). Text from Committee Reports. Available from https://www.congress.gov/congressional-report/104th-congress/housereport/458/1; Accessed: 4/14/17.

Waldman, S. (2011). Information needs of communities: The changing media landscape in a broadband age. DIANE Publishing. 
Appendix A

Austin 2015-2016 Cable Finances Detailed

\begin{tabular}{|c|c|c|c|}
\hline Revenues & Expenditures & Sums & Balance \\
\hline $\begin{array}{l}\$ 37,700,000 \text { Franchise Fees } \\
\text { (VOL 2, p.255) }\end{array}$ & $\begin{array}{l}\text { \$1,102,438 ATXN programs } \\
\text { (VOL 2, p.83) }\end{array}$ & $\begin{array}{l}\$ 39,600,000 \\
\text { Revenue }\end{array}$ & $\$ 37,725,000$ \\
\hline \multirow[t]{3}{*}{$\begin{array}{l}\$ 1,900,000 \text { PEG Fee Revenue } \\
\text { (VOL 2, p.263) }\end{array}$} & $\begin{array}{l}\$ 475,000 \text { Contracting fee from } \\
\text { general fund (VOL 2, p.263) }\end{array}$ & $\begin{array}{l}\$ 5,474,177 \\
\text { Expenditures }\end{array}$ & \\
\hline & $\begin{array}{l}\$ 1,875,000 \text { PEG related capital } \\
\text { expenditures (VOL 2, p.263) }\end{array}$ & & \\
\hline & $\begin{array}{l}2,021,739 \text { to TARA (VOL 2, } \\
\text { p.257) }\end{array}$ & & \\
\hline
\end{tabular}

All pages numbers listed from FY 2015-2016 Austin City Budget 
Appendix B

Charlotte 2016-2017 Cable Finances Detailed

\begin{tabular}{|c|c|c|c|}
\hline Revenues & Expenditures & Sums & Balance \\
\hline $\begin{array}{l}\$ 7,959,632 \text { Franchise } \\
\text { Fees (p.115) }\end{array}$ & $\begin{array}{l}\$ 3,449,234 \text { Network and } \\
\text { telecommunication } \\
\text { operations (p.93) }\end{array}$ & $\$ 8,059,632$ Revenue & $\$ 4,510,398$ \\
\hline $\begin{array}{l}\text { 100,000 "Carrier } \\
\text { Franchise Fees" (p.115) }\end{array}$ & & $\begin{array}{l}\$ 3,449,234 \\
\text { Expenditures }\end{array}$ & \\
\hline
\end{tabular}

All pages numbers listed from FY 2016-2017 Charlotte City Budget 
Appendix C

Chicago 2015-2016 Cable Finances Detailed

\begin{tabular}{llll}
\hline Revenues & Expenditures & Sums & Balance \\
\hline $\begin{array}{l}\$ 29,200,000 \text { Franchise } \\
\text { Fees (p.23) }\end{array}$ & $\begin{array}{l}\text { \$656,297 Cable and } \\
\text { telecommunication public } \\
\text { stations (p.115) }\end{array}$ & $\$ 29,200,000$ Revenue & $\$ 28,543,730$ \\
& & $\$ 6,56,297$ Expenditures & \\
\hline
\end{tabular}

All pages numbers listed from FY 2015-2016 Chicago City Budget 


\section{Appendix D}

\section{Columbus 2015-2016 Cable Finances Detailed}

\begin{tabular}{llll}
\hline Revenues & Expenditures & Sums & Balance \\
\hline $\begin{array}{l}\$ 9,600,000 \text { Franchise Fees } \\
\text { (p.16) }\end{array}$ & $\begin{array}{l}\text { \$1,055,233 Gov. television } \\
\text { channel (p.215) }\end{array}$ & $\$ 9,600,000$ Revenue & $\$ 8,544,767$ \\
& & $\$ 1,055,233$ Expenditures &
\end{tabular}

All pages numbers listed from FY 2015-2016 Columbus City Budget 
Appendix E

Dallas 2015-2016 Cable Finances Detailed

\begin{tabular}{llll}
\hline Revenues & Expenditures & Sums & Balance \\
\hline $\begin{array}{l}\text { 27,394,587 Franchise Fees } \\
\text { (p.561) }\end{array}$ & $\begin{array}{l}\text { \$1,521,441 Office of } \\
\text { Information Technology } \\
\text { (p.149) }\end{array}$ & $\$ 27,394,587$ Revenue & $\$ 24,827,352$ \\
& $\begin{array}{l}\$ 343,806 \text { Utility management } \\
(\mathrm{p} .181)\end{array}$ & $\begin{array}{l}\text { \$2,567,235 } \\
\text { Expenditures }\end{array}$ & \\
& $\begin{array}{l}\text { \$701,988 Street cut right of } \\
\text { way management (p.220) }\end{array}$ & & \\
& & \\
\hline
\end{tabular}

All pages numbers listed from FY 2015-2016 Dallas City Budget 
Appendix F

Detroit 2015-2016 Cable Finances Detailed

\begin{tabular}{|c|c|c|c|}
\hline Revenues & Expenditures & Sums & Balance \\
\hline $\begin{array}{l}\$ 5,000,000 \text { Franchise Fees } \\
\text { (p.C-73) }\end{array}$ & $\begin{array}{l}\$ 1,489,998 \text { Media services and } \\
\text { communication (p.B-193) }\end{array}$ & $\$ 8300000$ Revenue & $\begin{array}{l}\$ 6,310,002 \\
(\mathrm{~B}-187)\end{array}$ \\
\hline $\begin{array}{l}\$ 2,800,000 \text { Maintenance } \\
\text { Fees from telecomm } \\
\text { providers (p.B-187) } \\
\$ 500,000 \text { PEG revenue } \\
\text { (p.B-197) }\end{array}$ & 500,000 costs PEG (p.B-194) & $\$ 1,989,998$ Expenditures & \\
\hline
\end{tabular}


Appendix G

El Paso 2015-2016 Cable Finances Detailed

\begin{tabular}{llll}
\hline Revenues & Expenditures & Sums & Balance \\
\hline $\begin{array}{l}\text { \$8,767,956 Franchise Fees } \\
\text { p.88) }\end{array}$ & $\begin{array}{l}\text { \$200 Cable franchise review } \\
\text { services (p.102) }\end{array}$ & $\$ 8,767,956$ Revenue & $\$ 7,803,069$ \\
& $\begin{array}{l}\text { \$125,968 PEG (p.261) } \\
\text { \$838,719 PEG non } \\
\text { departmental (p.261) }\end{array}$ & $\$ 964,887$ Expenditures & \\
\hline
\end{tabular}

All pages numbers listed from FY 2015-2016 El Paso City Budget

PEG Fees included in but not separated from Franchise Fee revenue in budget (p.71) 


\section{Appendix $\mathrm{H}$}

\section{Fort Worth 2015-2016 Cable Finances Detailed}

\begin{tabular}{|c|c|c|c|}
\hline Revenues & Expenditures & Sums & Balance \\
\hline $\begin{array}{l}\$ 6,680,684 \text { Franchise Fees } \\
(\text { p.F-12) }\end{array}$ & $\begin{array}{l}\$ 300,000 \text { Cable Office Fund } \\
\text { (p.E-100) }\end{array}$ & $\$ 7,880,684$ Revenue & $\$ 6,680,684$ \\
\hline $\begin{array}{l}\$ 1,200,000 \text { PEG Fees } \\
\text { (p.H-317) }\end{array}$ & $\begin{array}{l}\text { 900,000 Transfers and Others } \\
\text { (p.H-318) }\end{array}$ & $\$ 1,200,000$ Expenditures & \\
\hline
\end{tabular}

All pages numbers listed from FY 2015-2016 Fort Worth City Budget 
INVESTIGATING CABLE

Appendix I

Houston 2015-2016 Cable Finances Detailed

\begin{tabular}{llll}
\hline Revenues & Expenditures & Sums & Balance \\
\hline $\begin{array}{l}\text { \$23,900,000 Franchise } \\
\text { Fees (p.11-7) }\end{array}$ & $\begin{array}{l}\text { 2,570,307 Maintenance and } \\
\text { operations for PEG (p.x-88) }\end{array}$ & $\$ 28,679,900$ Revenue & $\$ 23,672,343$ \\
$\begin{array}{l}\text { \$5,286,382 PEG Fees (p.x- } \\
88)\end{array}$ & $\begin{array}{l}\text { 2,347,250 Contracts with } \\
\text { nonprofit (p.x-88) }\end{array}$ & $\$ 4,917,557$ Expenditures & \\
\hline
\end{tabular}

All pages numbers listed from FY 2015-2016 Houston City Budget

Of the $\$ 5,286,382$ in PEG Revenue only $\$ 4,779,900$ is new revenue in fy16 (p.x-88)

368,825 of PEG funding was reserved for the next fiscal year 
Appendix $\mathbf{J}$

Indianapolis 2016-2017 Cable Finances Detailed

\begin{tabular}{llll}
\hline Revenues & Expenditures & Sums & Balance \\
\hline $\begin{array}{l}\text { \$556,193 PEG Fee Revenue } \\
\text { (p.22) }\end{array}$ & $\begin{array}{l}\$ 343,275 \text { Personal services } \\
\text { (p.77) }\end{array}$ & $\$ 556,193$ Revenue & $\$ 0$ \\
& $\begin{array}{l}\$ 1,900 \text { Material and services } \\
\text { (p.77) }\end{array}$ & $\$ 556,193$ Expenditures & \\
& $\begin{array}{l}\$ 179,289 \text { Other services and } \\
\text { charges (p.77) }\end{array}$ & & \\
& & & \\
& & & \\
& equipment (p.77) & & \\
& & & \\
& & & \\
& equipment (p.77) & & \\
\hline
\end{tabular}

All pages numbers listed from FY 2015-2016 Indianapolis City Budget

Franchise Fees are received at the state level and not reported in the city budget 
Appendix K

Jacksonville 2015-2016 Cable Finances Detailed

\begin{tabular}{llll}
\hline Revenues & Expenditures & Sums & Balance \\
\hline $\begin{array}{l}\$ 35,300,000 \text { Reported as } \\
\text { aggregate of all franchise }\end{array}$ & Unreported & Revenue unreported & Unreported \\
fees including phone etc. & & & \\
(p.133-135) & & Expenditures unreported &
\end{tabular}

All pages numbers listed from FY 2015-2016 Jacksonville City Budget 
Appendix L

Los Angeles 2015-2016 Cable Finances Detailed

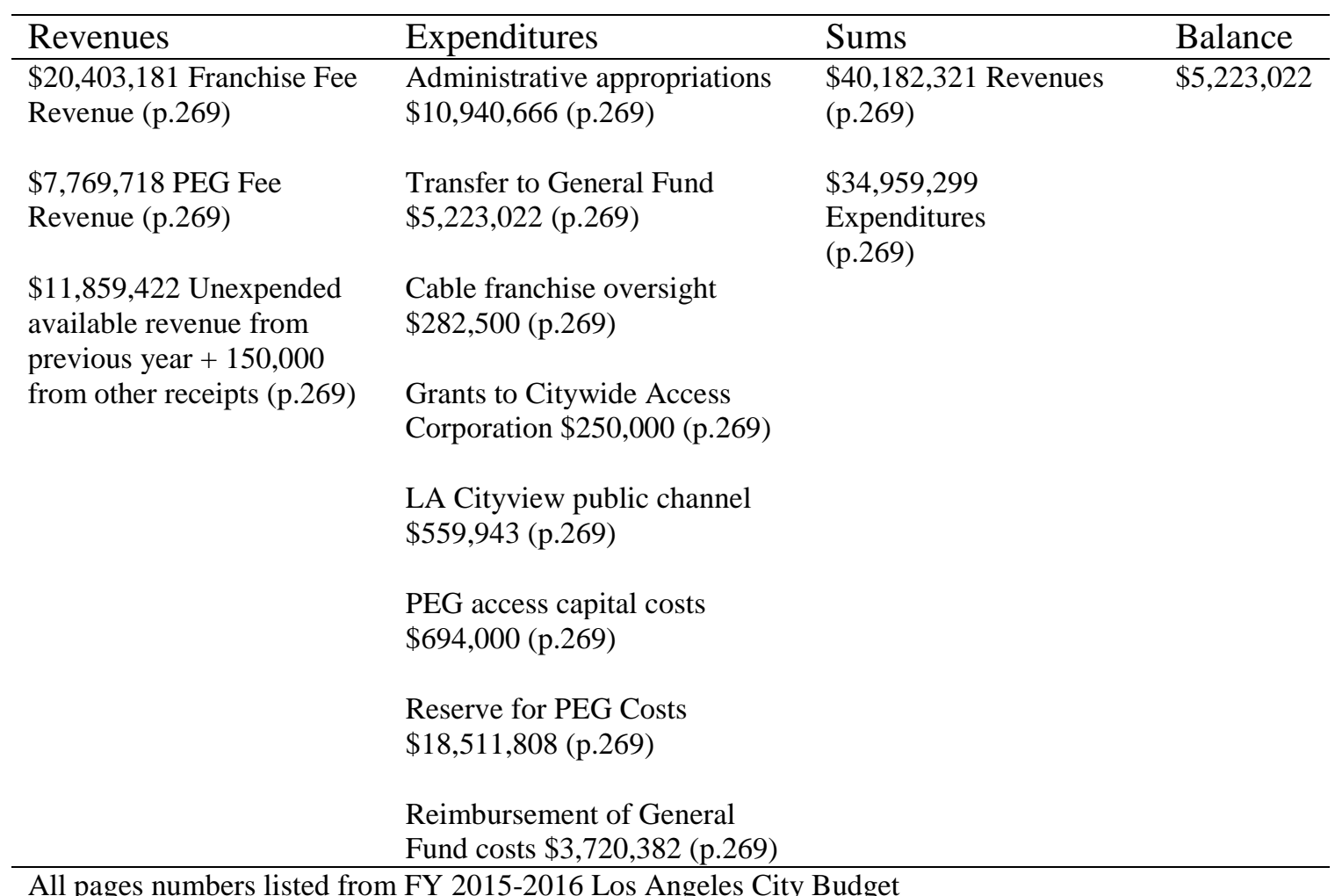

All pages numbers listed from FY 2015-2016 Los Angeles City Budget 


\section{Appendix M}

New York 2015-2016 Cable Finances Detailed

\begin{tabular}{lll}
\hline Revenues & Expenditures & Sums \\
\hline \$160,847,000 Franchise & $\$ 36,241,332$ Dept. of Info & $\$ 160,847,000$ Revenue \\
Fees listed with “Other & Tech and Telecomm (p.351- & \\
Permits and Privileges" & E) & \\
(p.21R) & & $\begin{array}{l}\text { Expenditures unknown. } \\
\end{array}$ \\
& & $\begin{array}{l}\$ 36,241,332 \text { is an } \\
\text { aggregate amount }\end{array}$ \\
& & including services \\
& outside of cable costs.
\end{tabular}

All pages numbers listed from FY 2015-2016 New York City Budget

The Department of Information and Technology develops municipal use of cable TV in addition to other municipal telecomm services, and thus is an aggregate amount. 
Appendix N

Philadelphia 2015-2016 Cable Finances Detailed

\begin{tabular}{llll}
\hline Revenues & Expenditures & Sums & Balance \\
\hline $\begin{array}{l}\$ 21,442,000 \text { Franchise Fees } \\
\text { (p.13) }\end{array}$ & Unreported & $\$ 21,442,000$ & Unreported
\end{tabular}

All pages numbers listed from FY 2015-2016 Philadelphia Mayor's operating budget. 


\section{Appendix O}

Phoenix 2015-2016 Cable Finances Detailed

\begin{tabular}{|c|c|c|c|}
\hline Revenues & Expenditures & Sums & Balance \\
\hline \multirow[t]{5}{*}{$\begin{array}{l}\$ 9,500,000 \text { Franchise Fees } \\
(\text { p.440) }\end{array}$} & $\begin{array}{l}\$ 5,362,000 \text { Transfer to general } \\
\text { fund (p.469) }\end{array}$ & $\begin{array}{l}\$ 9,500,000 \\
\text { Revenue }\end{array}$ & $\$ 3,069,651$ \\
\hline & $\begin{array}{l}\$ 1,948,000 \text { Public information } \\
\text { (p.469) }\end{array}$ & $\begin{array}{l}\$ 11,792,349 \\
\text { Expenditures }\end{array}$ & \\
\hline & $\begin{array}{l}\$ 1,770,000 \text { Street transportation } \\
\text { (p.469) }\end{array}$ & & \\
\hline & $\begin{array}{l}\$ 420,000 \text { Information technology } \\
\text { (p.469) }\end{array}$ & & \\
\hline & $\begin{array}{l}\$ 2,292,349 \text { Communications } \\
\text { office (p. } 17)\end{array}$ & & \\
\hline
\end{tabular}




\section{Appendix P}

San Antonio 2015-2016 Cable Finances Detailed

\begin{tabular}{llll}
\hline Revenues & Expenditures & Sums & Balance \\
\hline $\begin{array}{l}\text { \$30,700,000 Franchise } \\
\text { Fees (p.115) }\end{array}$ & $\begin{array}{l}62,410 \text { Studio facilities and } \\
\text { equipment's administration } \\
\text { (p.139) }\end{array}$ & $\$ 30,700,000$ Revenue & $\$ 30,487,590$ \\
& $\begin{array}{l}\text { 150,000 Alamo public } \\
\text { telecommunications school } \\
\text { readiness (p.358) }\end{array}$ & $\$ 212,410$ Expenditures & \\
& & & \\
\hline
\end{tabular}

All pages numbers listed from FY 2015-2016 San Antonio City Budget 


\section{Appendix Q}

San Diego 2015-2016 Cable Finances Detailed

\begin{tabular}{llll}
\hline Revenues & Expenditures & Sums & Balance \\
\hline $\begin{array}{l}\$ 18,600,000 \text { Franchise Fees } \\
\text { (p.70) }\end{array}$ & $\begin{array}{l}\$ 3,563,052 \text { Communication } \\
\text { Office (p.132-134) }\end{array}$ & $\begin{array}{l}\$ 18,600,000 \\
\text { Revenue }\end{array}$ & $\$ 13,336,948$ \\
& $\begin{array}{l}\$ 1,700,000 \text { City TV PEG for } \\
\text { library improvement (p.161) }\end{array}$ & $\begin{array}{l}\$ 5,263,052 \\
\text { Expenditures }\end{array}$ & \\
& & & \\
&
\end{tabular}

All pages numbers listed from FY 2015-2016 San Diego City Budget 
Appendix R

San Francisco 2015-2016 Cable Finances Detailed

\begin{tabular}{llll}
\hline Revenues & Expenditures & Sums & Balance \\
\hline 3,090,700 Reported as licenses & $97,292,347$ Department of & $\$ 3,090,700$ & Cannot be \\
and fines (p.257) & Revenue & determined. \\
& & Expenditures & \\
& & unknown. \\
& Department of \\
& Technology is an \\
& aggregate of & \\
& many expenses \\
& outside of cable. & \\
& & & \\
& & & \\
& &
\end{tabular}

All pages numbers listed from FY 2015-2016 San Francisco Budget

Department of Technology does many things including architecture security, public safety, administration and finance, service delivery, and finally public TV (p.253) 
Appendix S

San Jose 2015-2016 Cable Finances Detailed

\begin{tabular}{llll}
\hline Revenues & Expenditures & Sums & Balance \\
\hline $\begin{array}{l}\text { \$9,900,000 Franchise Fees } \\
\text { (Attachment A, p.5) }\end{array}$ & $\begin{array}{l}460,000 \text { Re-budget for facilities } \\
\text { (p.IX-5) }\end{array}$ & $\begin{array}{l}\$ 11,900,000 \\
\text { Revenue }\end{array}$ & $\$ 8,591,208$ \\
$\begin{array}{l}\text { \$2,000,000 PEG Revenue } \\
\text { (p.VI-50) }\end{array}$ & 144,000 Access facilities (p.IX-7) & $\begin{array}{l}\$ 3,308,792 \\
\text { Expenditures }\end{array}$ & \\
& 461,396 Access facilities (p.IX- & & \\
& $20)$ & & \\
& $2,243,396$ PEG costs (p.IX-29) & & \\
& & & \\
\end{tabular}

All pages numbers listed from FY 2015-2016 San Jose City Budget 
Appendix T

Seattle 2015-2016 Cable Finances Detailed

\begin{tabular}{llll}
\hline Revenues & Expenditures & Sums & Balance \\
\hline $\begin{array}{l}\$ 8,645,104 \text { Franchise Fees } \\
\text { (p.447) }\end{array}$ & 190,000 Public library (p.143) & $\$ 8,645,104$ Revenue & $\$ 227,275$ \\
& $\begin{array}{l}\text { 8,227,829 Information } \\
\text { Technology Fund (p.447) }\end{array}$ & $\$ 8,417,829$ Expenditures & \\
& & & \\
\hline
\end{tabular}

All pages numbers listed from FY 2015-2016 Seattle Budget.

$3,661,739$ of the disbursement to the information technology fund went to funding Seattle's public access channel (p.447). 
Appendix U

Cable franchises per city

\begin{tabular}{ll}
\hline City & Major Cable Franchise(s) \\
\hline Austin & Comcast; Time Warner \\
Charlotte & Comcast; Time Warner \\
Chicago & Comcast \\
Columbus & Time Warner; AT\&T \\
Dallas & Time Warner; AT\&T \\
Detroit & Comcast; AT\&T \\
El Paso & Time Warner; AT\&T \\
Fort Worth & Time Warmer; Verizon \\
Houston & Comcast; AT\&T \\
Indianapolis & Comcast; AT\&T \\
Jacksonville & Comcast; AT\&T \\
Los Angeles & Time Warner \\
New York & Time Warner; AT\&T \\
Philadelphia & Comcast; AT\&T \\
Phoenix & Comcast; Cox \\
San Antonio & Time Warner \\
San Diego & Time Warner \\
San Francisco & Time Warner; AT\&T \\
San Jose & Comcast; AT\&T \\
Seattle & Comcast; AT\&T \\
\hline
\end{tabular}

